\title{
XIV. Supplementary Observations on Quartz Rock, made in 1814.
}

By J. Mac Culzoch, M.D. F.L.S. President of the Geological Society, Chemist to the Ordnance, Lecturer on Chemistry at the Royal Military Academy, and Geologist to the Trigonometrical Survey.

[Read 17th February, 1815.]

Having had an opportunity during the present summer of adding some further remarks to the observations on quartz rock, I have here arranged them as a supplement to the former papers, for the purpose of extending the history and connections of this important member of the more ancient strata. As I had not the means of examining a very wide extent of country, I have not been able materially to enlarge its geographical boundaries, yet the Society will see that it constitutes a very considerable part of the country I did observe. It is found in most parts of the valley of the Tumel, which extends from the head of Loch Rannoch to the junction of the Tumel with the Garry. Throughout this whole extent it alternates with schist, sometimes micaceous, now and then containing felspar and thus resembling gneiss in composition, but oftener argillaceous, and very hard, from the large proportion of quartz which it contains. As we approach the lower end of this valley the quartz rock diminishes, while the schist increases, until the former at length disappears. Beds of limestone are found alternating with it throughout this course: it also contains porphyry, of which numerous masses are to be seen on the sides of Loch Rannoch. These 
Dr. Mac Culloch's Supplementary Observations, \&ْc. 265

masses are sometimes truly porphyritic, containing crystals of felspar, while at other times they consist of an uniform reddish compact felspar, the usual basis of those porphyries which are found associated with the primary rocks. There is much difficulty in determining the true nature of these porphyritic masses. Occasionally they seem to cut the strata, while in other places there can be no question that they are parallel to them. Nevertheless I am still inclined to think that even those which are occasionally seen conforming to the position of the strata in which they lie, are, like the masses of trap which have a direction parallel to the associated beds, only veins, of which the direction is so far parallel to the position of the beds in which they are found.

From Loch Rannoch the quartz rock is seen crossing the mountains to Loch Ericht, accompanied in the same way with the various schists, and finally terminating in different places round the outskirts of Ben Vualach, where its junction with the granite of this mountain is visible. It may then be traced along the southern border of Loch Ericht, where it joins with a similar series of rocks that will be found extending from Dalwhinnie along the course of the Truim, and then along that of the Garry all the way to Blair. A fact of some importance is visible at Loch Ericht which I will mention here, although not particularly connected with the history of quartz rock. About half way between the top and bottom of the lake on the south side, a large slide of the mountain is to be seen; the ruin is still so entire, of such magnitude, and so little encumbered with recent accumulations of soil, that there is no difficulty in tracing the fallen masses to the broken summits whence they were detached. The quartz rock here, as in all the outskirts of this granitic country, is traversed by granite veins. A few fallen stones have formed a sort of cave cabable of containing three or four persons, and known 
to the neighbouring shepherds, who, still mindful of their ancient allegiance, show the spot where, among many others, the unfortunate Prince was for a time concealed. The minuter fragments of quartz rock and granite have here formed themselves into angular conglomerates, which are in some instances perfectly compact, the smaller cavities having been filled up by siliceous matter, while the larger fragments, touching only by small surfaces, have left considerable openings between them. Here then we have an example of a breccia formed in times comparatively recent. The conglomeration of the fragments is not the effect of the accidental presence of iron, so commonly the cement of modern breccias, but is evidently the result of a deposition of siliceous matter. This could only have been brought into solution by the rains, or by the operation of common water, since the stones are out of the reach of other causes, and it serves to prove that the solution of silica in water, a circumstance which some have supposed limited to the ancient state of the Globe, is a process still going on. I have indeed noticed in the former remarks on quartz rock the same fact as proved by the enamelled and polished surface which its exposed parts so often assume. We have no means from historical record of determining the antiquity of this slide, but as far as any conjectural evidence can be adduced from the little accumulation of soil which has formed on the horizontal surfaces, and the bare aspect of the faces, on which scarcely a lichen has yet planted itself, it cannot be of very high antiquity. The observation is further of importance as illustrating the origin of the brecciated jaspers, as well as that of the other breccias formed of angular fragments.

From Loch Ericht the quartz rock branches away to the mountains that skirt Ben Nevis and Glenco, as I noticed in the above mentioned paper. I have already observed in that paper that it 
constituted a portion of Schihallien and of the northern side of Glen Lyon, terminating in the micaceous and chlorite schist of the ridge of Ben Lawers. Taking it up now from Blair we shall find it occupying a large proportion of the whole group of hills which lies between the Bruer and the Tilt, lying over the granite and stretching away towards Glen Dee, and thus uniting with that tract of it which I also described last year as skirting the great granite mass of the Grampians towards its eastern declivity. Returning again to Blair it is found extending over the whole ridge of Ben Gloe, and here it scarcely ever alternates with schist. From Ben Gloe it may be traced over the Scarsough into Mar, forming at the same time Cairn ree and a considerable extent of the hills which skirt Glen Fernat and Strath Airdle to the eastward. From Mar it is then seen to form a principal portion of the tract which bounds Glen Shee on both sides, but further into the hills of Angus I have had no opportunity of following it. If the several spaces which $I$ have described here and in the former paper, be marked on the map, it will be seen to occupy a very large portion of the country, and one which will I doubt not be easily extended. I do not mean to lay it down as a rule, (since the irregular position of this class of rocks is such that they scarcely admit of any rule), but I think it will be found here most abundant in the vicinity of the granite, while the micaceous schist on the contrary lies at the greatest distance from it. A mineralogical map of Scotland, a work as yet far distant, will probably confirm the generality of this remark.

I have but little to add to the particular description of the rock and of its several varieties given in the above named paper, but there are a few circumstances worthy of record.

In Ben Gloe it is found incurvated and contorted in the manner of micaceous schist, a proof that, like all the other schistose rocks 
with which we are acquainted, it has occasionally been in a flexible state. Some beds are also to be found there towards the east, on that shoulder of Cairn Gower which hangs towards Loch Lochs, containing rounded pebbles, such as I before described as occurring in it at Jura. The beds in which this variety is found consist indeed entirely of a loose aggregation of large and small rounded gravel. This is only the second instance in which $I$ have noticed a coarse conglomerate mass as forming one of the varieties of quartz rock. The pebbles are of considerable magnitude, and bear just such marks of attrition as do those which have been rolled on a sea shore: if they are not mechanically rounded pebbles I know not where such can be found. I have little doubt that this variety will oftener occur when these rocks shall have been more extensively examined; but I trust this fact is no longer necessary to prove that quartz rock bears the marks of a mixed mechanical origin, and that it thus serves to determine in some measure a corresponding set of circumstances in which the schistose rocks associated with it were formed.

Near Blair it may be observed passing into a regular granite in a very distinct manner. Many of the specimens found were transported stones, but in many other instances, which I have had occasion to notice in a paper on Glen Tilt,* the transition from quartz rock to granite is to be seen in situ. I have there also noticed that, which ought for the sake of uniformity to be repeated here, that the beds of quartz rock which are in immediate contact with the granite often pass into it by insensible degrees. It is well known that there is a gradual transition from mica slate into gneiss, and that this rock again by degrees equally evanescent passes into granite. I have shown that quartz rock is here in contact with granite, and it is not therefore surprizing that it should, like the mica slate with which it 
forms but one great deposit, undergo analogous changes when it approximates to this rock. The transition is in fact more easy and the boundary less definable, since many varieties of quartz rock, formed of felspar and quartz in varying proportions with an occasional mixture of mica, only require to assume that crystallized appearance which the vicinity of granite is so apt to produce on the neighbouring rocks, to become undistinguishable from it. The quartz rock in these specimens contains mica, disposed at first in a parallel form, so that it might equally be ranked among the varieties of micaceous schistus or of gneiss. By degrees the mica loses its parallel disposition, and at length the whole assumes the aspect of granite. This transition therefore adds one more to those passages into mica slate, clay slate, and graywacké, which I formerly described as occurring in quartz rock. Loose specimens are found both at Blair and in Ben Gloe containing drusy cavities, of which the siliceous crystals, though more minute than a pin's head, are perfectly defined. These crystals are evidently of posterior formation to the general mass of the rock, and have resulted from the infiltration of a watery solution of silica into previously formed cavities. They prove no. thing therefore relating to the chemical nature of this rock, of which, mixed with its mechanical formation, there are every where to be found abundant examples, some of which I have formerly enume. rated.

In Glen Tilt I have taken out specimens from the beds exactly similar to those long compressed and smooth cylindrical bodies which are sometimes found in secondary sandstones. This shows another distinct point of agreement between quartz rock and those sandstones. In the same place is found a very interesting variety. It consists of a regular and repeated alternation of quartz with common argillaceous schist; the smoothest variety of clay slate. The quartz at

Vor. IV.

$2 \mathrm{M}$ 
the same time is compact and crystalline, differing in no respect from the most common specimens of this substance. The alternations are such and so frequent that a cross fracture of this rock may almost be compared to the striped leaf of arundo colorata.

In another situation I observed specimens consisting of pure quartz without any such mixture of clay, but so fissile as to scale off in leaves as thin as paper.

Although garnets abound so much in mica slate, I have only met with one instance in which they occur in quartz rock; this is at the west end of Mar forest near the Dee. The garnets however are very incomplete, although large in size; they occupy only the intervals between the layers of the stone, and on splitting it are found as if compressed between the surfaces.

Another remarkable variety of this rock also occurs in Glen Tilt. It resembles precisely the schistose sandstones which accompany the coal strata, and is found in distinct laminæ from an eighth to a quarter of an inch in thickness, detached from each other and separated by thinner laminæ of loose mica or clay. It offers another example of the striking resemblance between quartz rock and the secondary sandstones; an agreement much more remarkable than that of the mica slate which generally accompanies it, with the slate clay which is the associate of those sandstones. It would seem as if the quartz rock from its greater simplicity of materials, a simplicity less liable to chemical changes, had undergone fewer alterations during the progress of time and of those actions by which its present form was produced, than the more compound schist with which it was originally associated. In those varieties of quartz rock which are, like that last described, formed of distinct laminæ, natural joints occur resembling those of clay slate and producing on fracture, 
rhomboidal tables. In this respect it bears a considerable analogy to the clay slates with which it is so often associated.

Among the varieties found in Ben Gloe I remarked some others worthy of notice, considering the novelty of this subject and the necessity of describing every remarkable feature of a rock so long overlooked or confounded with others. The most singular of these is of a beautiful pink colour, equal to that of the well known rose quartz, with the semi-transparency and fine grain of the most highly refined sugar: it forms interesting specimens for collectors of minerals. I have mentioned it in describing Glen Tilt. Another is of a dark brown colour, apparently from containing much carbonate of iron, but when it is exposed to the weather the surface is bleached to the depth of a quarter of an inch and becomes of a snowy whiteness. A third is of an ochre yellow colour and loose texture, and in hand specimens not to be distinguished from a common secondary sandstone, while at the same time it contains distinct concretions of crystallized carbonate of lime irregularly dispersed through it. A variety equally resembling some of the secondary sandston 8 which occur among the coal strata in the vicinity of Glasgow and elsewhere, is found near Balahulish. It is distinguished by the frequent alternation of black laminæ, of which the cross fracture represents delicate lines, and it serves with others already enumerated to confirm the strong affinity of the recent sandstones with quartz rock, the sandstone of former ages.

Among the various modifications of guartz rock which I have observed in the different districts now described, a great many exhibit the characters of the avanturine, the quartz avanturine of Brongniart. I have frequently noticed the transition which takes place between quartz rock and mica slate, a transition so gradual and so perfect that it is often impossible to assign the limits of the two. The quartz 
is often hyaline, while the mica is disseminated through it in scales of which the tendency, notwithstanding the crystalline state of the quartz, is parallel either to the laminæ or to the beds of the stone. These specimens when polished exhibit the characters of the most perfect avanturine, but their colours aré only white or greyish. I have never yet met with the most esteemed, the yellow variety. As the quartz rock approaches more nearly to mica slate, the character of the specimens which resemble avanturine changes, until they resemble the variety of this ornamental mineral found at Ekaterineberg. In many cases the scales of mica have a considerably greater dimension in one direction than in another, from which the stone acquires a fibrous aspect. This variety; of a fine blue grey colour, occurs in Glen Fernat in large beds, and when polished does not yield to some of the most beautiful foreign specimens of avanturine. 'There is yet one other modification of this mineral, of which the splendour results merely from the varying position of the quartz grains which form it. The most crystallized and pure specimens of quartz rock afford-this variety, and examples of it are to be found every where among the more compact beds of that rock. We may therefore conclude that the avanturine, so much esteemed and long so ill understood, is a variety of quartz rock; a circumstance likely to give this rock that importance among collectors of specimens, which I have attempted to claim for it among geologists. 
on Quartz Rock.

Further Observations.

[Read 20th December, 1816.]

For the sake of rendering somewhat more complete the history of this substance, I shall here subjoin an account of a considerable body of it which is to be seen in a very unexpected situation in Sky. Although it will be found mentioned in the present volume, in a supplementary paper on that island, it will not be irrelevant to describe it in somewhat greater detail here.

A series of stratified rocks is found extending from the Kyle ric' $h$, on the eastern side of this island, to Loch Eishort, on its western side, and occupying a considerable space laterally, or consisting of a frequent repetition of the substances which constitute it. While the nature of these strata, which present alternations of red'sandstone with graywacké schist, and with indurated grey and blue granular quartz, would incline us to rank them among the secondary rocks, some doubt is thrown on that conclusion in consequence of the peculiar relation they bear to the older rocks which they follow, the gneiss, and the micaceous and chlorite schists. But I must refer to the paper on Sky itself, for the history of these strata, and limit myself to the description of the particular rock which is the object of this note.

It forms a large mass of strata in an erect position, running parallel with the red sandstone and the graywacke schist, which, in repeated alternations, lie on each side of it. These strata, always 
highly elevated, are in some parts vertical, while in others they incline, like the rocks by which they are accompanied, sometimes in one direction and at others in the opposite one, from the perpendicular, their bearing being north-easterly. Although the accompanying strata extend from one shore of the island to the other, the quartz rock in question does not attend them throughout, the total length which its leading mass occupies being limited to about five miles, as nearly as that can be ascertained. Its south-western end will be found in the hills behind the castle of Dunscaich, and its north-eastern approaches the shore of Loch Eishort, nearly opposite to a small island which forms the innermost harbour of that branch of the sea. The collective breadth of the strata where they. are widest, appears to be about a mile and a half, while at each end it is much less, but the nature of the ground does not permit their whole extent or geographic shape to be accurately ascertained. In a general view they form two irregular ranges of parallel elevations, with shallow intermediate vallies, and as these summits maintain scarcely any vegetation, while they are composed of white compact quartz, their effect is very striking, even at a great distance; presenting the appearance of a fall of recent and thin snow.

Besides this leading mass, many detached portions of strata of the same substance are to be seen in the neighbourhood, and they are most accessible on the shore from Dunscaich to Ord. In these places their alternation with the red sandstone and greywacké schist can be traced with great ease and satisfaction, while at the same time their stratified disposition and their angles of inclination may be examined in considerable detail. The small island of Dunscaich, remarkable for the remains of a Danish strength, and a more probable residence of the traditional king of the Isle of Mist than the neighbouring promontory, affords particular facilities for examining 
the nature and disposition of this rock. Here it is disposed in thin beds, rarely exceeding a few inches in thickness, and is inclined towards the east in an angle of about 26 degrees. These beds are divided by natural joints, at angles with the plane of stratifcation, and in consequence of this they break into prismatic rhomboidal or triangular fragments, which on the upper and lung-exposed surfaces are so numerous and minute that the whole presents at first sight a set of sharp points and projections, among which the stratified disposition is scarcely perceived until they are more closely examined. The same disposition into thin strata is every where found throughout the larger masses, and if sometimes more obscure, it can nevertheless be always discovered by an attentive examination.

With respect to the composition of this rock it is almost always found to be a compact splintery quartz, scarcely distinguishable in small fragments from that mineral as it occupies veins. Occasionally it becomes more or less granular, and now and then will be found to contain grains of felspar, as it does in so many other places. Its prevalent colour is white, but it sometimes assumes a rusty colour at a small depth from the surface, and in some rare instances may be observed of a pink and of a brown-reddish hue.

If there is any transition between this rock and those with which it is associated, it must be sought among those beds which approach to a granular structure, between which and the most compact varieties of the red sandstone the difference is not extremely great. I cannot say that I have positively ascertained such a transition, nor am I aware that the nature of the ground is such as to admit of an examination sufficiently connected and extensive to answer this purpose. I shall however point out to geologists that part of 
276 Dr. Mac Cul zoch's Supplementary Observations, छc. the shore which lies to the eastward of Ord, as particularly interesting in this view; since, if it does not present examples of an exact and satisfactory transition between the two rocks, it affords very instructive views of the change which, under particular circumstances, occurs in the sandstones, from the distinctly granular and arenaceous to the compact and quartzose state. 